\title{
Assessment of timber extraction distance and skid road network in steep karst terrain
}

\author{
Andreja Duka ${ }^{(1)}$, \\ Stefano Grigolato ${ }^{(2)}$, \\ Ivica Papa ${ }^{(1)}$, \\ Tibor Pentek ${ }^{(1)}$, \\ Tomislav Poršinsky ${ }^{(1)}$
}

\begin{abstract}
This study aims to define a simple and effective method to calculate skidding distances on steep karst terrain, rich in ground obstacles (stoniness and rockiness) to support decision planning of secondary and primary forest infrastructure network for timber extraction in productive selective cut forests. Variations between geometrical extraction distances and actual distances were highlighted on the operational planning level (i.e., compartment level) through GIS-related calculation models, focusing on cable skidder timber extraction. Automation in defining geometrical and real extraction distances, as well as relative forest openness were achieved by geo-processing workflows in GIS environment. Due to variation of extraction correction factors at the compartment level from a minimum of 1.19 to a maximum of 5.05 in the same management unit, it can be concluded that planning harvesting operations (timber extraction) at operational level should not include the use of correction factors previously obtained for entire terrain (topographical) categories, sub-categories or even management units.
\end{abstract}

Keywords: Real Extraction Distance, Steep Terrain, Skid Road Network, GIS Environment, Karst Terrain its uneven conditions that affect road network asymmetry together with non-linear and non-vertical timber movement to forest road which occur during timber extraction. Optimal forest openness (i.e., forest accessibility) represents the final goal of opening forests with roads and starts from the least cumulative costs of timber extraction together with building and maintenance costs of forest roads (Dietz et al. 1984, Silversides \& Sundberg 1988, Sessions 2007). Road density values do not give information about quality of road network layout in the forest stand (Pentek et al. 2004), but simply of their quantity and therefore cannot be used for evaluating the current or future state of forest openness. On the other hand, relative openness as a quality parameter introduced by Backmund (1966) is still used in grading forest openness but with variations in buffer width (Hayati et al. 2012). Timber extraction distance (or skidding distance) as a pa-
(1) Department of Forest Engineering, Faculty of Forestry, University of Zagreb, Svetošimunska 25, Zagreb (Croatia); (2) Department of Land, Environment, Agriculture and Forestry, University of Padova, v.le Dell'Università 16, Legnaro, PD (Italy)

@ Andreja Duka (aduka@sumfak.hr)

Received: Apr 24, 2017 - Accepted: Aug 13, 2017

Citation: Duka A, Grigolato S, Papa I, Pentek T, Poršinsky T (2017). Assessment of timber extraction distance and skid road network in steep karst terrain. iForest 10: 886-894. - doi: 10.3832/ifor2471-010 [online 2017-11-06]

Communicated by: Rodolfo Picchio rameter has a great influence in machine productivity and costs (Valeria et al. 2011) thus affecting the whole timber supply chain.

Literature review shows that factors regarding timber extraction distance have been changing through time, firstly introduced by Segebaden (1964) as: (i) V-corr or network correction factor; and (ii) T-corr or off-road correction factor. Folegatti (2010) and Ackerman et al. (2014) for "off-road correction factor" refer to as "wander factor", while Silversides \& Sundberg (1988) call it "winding factor". Various authors give different values for off-road correction factor, depending on terrain (topographical characteristics), from 1.2 to 2.5 (Dietz et al. 1984, Segebaden 1964, Backmund 1966), road network layout (Sessions 2007), organizational level of timber extraction activities (Krč \& Košir 2008) and machine type, along with working methods (Folegatti 2010, Kulak et al. 2017). Most authors consider landing site position and road network layout to be the most significant factors affecting average extraction distance (Greulich 1997, Contreras \& Chung 2007).

Fundamental approaches in defining average extraction distances are still widely in use nowadays supported in GIS technologies (Halleux \& Greene 2001, Grigolato et al. 2017) which allow more detailed planning (Jourgholami et al. 2013) and optimisation of both primary (extraction) and secondary (long-distance) timber transportation alternatives (Contreras \& Chung 2011, Hayati et al. 2012).

From all stated above, one can conclude 
that differences in estimating average extraction distances can therefore be found in: (i) theoretical model vs. actual state, (ii) level of planning, i.e., management unit vs. compartment/sub-compartment level; and (iii) forest road layout in forest stand (geometry) vs. real timber extraction distance with defined vehicle/system.

In terms of forest management, choosing a vehicle for timber extraction will depend on many conditions (Allman et al. 2015), but terrain slope (Heinimann 1999), ground obstacles (Visser \& Berkett 2015) and soil bearing capacity (Amishev et al. 2009), as well as primary and secondary forest infrastructure network, take an important part in overall vehicle choice. Steep terrain slope and/or ground obstacles affect longitudinal and lateral vehicle stability, with that their mobility, productivity and work safety (Visser \& Berkett 2015, Visser \& Stampfer 2015, Ackerman et al. 2016). On the other hand, some authors highlight the importance of shape, position and density of secondary forest infrastructure network, i.e., skid roads and skid trails (Pentek et al. 2010) as being critical parameters for basic vehicle-to-timber access during timber extraction (length of winch rope or boom reach). Also, timber harvesting is highly influenced by road network structure (Cavalli \& Grigolato 2010) and therefore cost-effective transport is a must.

High surface heterogeneities such as steep slopes, changes in aspect directions and high amount of ground obstacles are common in area of high karst (Leucci \& De Giorgi 2005), while various complexities of ground conditions such as caves, sinkholes and rockhead relief result as very difficult ground for civil engineers to overcome (Waltham \& Fookes 2003). Zhang et al. (2010) highlight that karst landscape is distributed all over the world, but is mainly found in Eastern Europe and European Mediterranean, North America, and China with the largest and widest karst area. In Croatia, $46 \%$ of land $(2,578,000$ ha) is karst terrain (Herak \& Stringfield 1971), where the most common tree species - common beech (Fagus sylvatica L.) and silver fir (Abies alba Mill.) - comprise selective forests of great management and ecological value.

This study aims to define a simple and effective method to calculate skidding distances in steep karst terrain to support decision on planning secondary (skid roads) and primary (truck roads) forest infrastructure network for timber extraction.

Main hypothesis of this research is that there are clear differences between geometrical and actual skidding distances, and those will be highlighted at the operational planning level (i.e., compartment level) with accompanying GIS-related calculation models in a case study of timber extraction by a cable skidder in steep karst terrain and built secondary forest infrastructure network.

Automation in defining geometrical and real extraction distances, as well as relative forest openness will be achieved by using geo-processing workflows in GIS environment which will allow future use of models in varying conditions.

\section{Materials and methods}

\section{Study area}

The study was conducted in beech and fir selective forests of pre-mountainous area of Croatia, in the Management Unit (MU) Kupjački vrh, located at $45^{\circ} 26^{\prime} \mathrm{N}$ latitude and $14^{\circ} 53^{\prime}$ E longitude. The Kupjački vrh MU consists of about 279 hectares of forests, of which 275 ha is productive forest area. The MU is divided into $16 \mathrm{com}$ partments and average growing stock is $446 \mathrm{~m}^{3} \mathrm{ha}^{-1}$, with an annual increment of $6.25 \mathrm{~m}^{3} \mathrm{ha}^{-1}$. The $53 \%$ of growing stock is above $50 \mathrm{~cm} \mathrm{DBH}$ and $35 \%$ is between 31 and $50 \mathrm{~cm} \mathrm{DBH}$. Over a period of 10 years (2015-2024) total allowable cut is 24,850 $\mathrm{m}^{3}$.

The Kupjački vrh MU is representative of high karst with many karst phenomenon and a centrally located peak from which terrain descends in all exposition directions. Mechanical soil composition in the area is highly skeletoid without a developed hydrological network (Đuka et al. 2017).

In the study area, harvesting is traditionally performed by chainsaws and timber extraction is done by cable skidders with tree length or half-tree length system.

Without skid roads vehicle mobility would not be possible in this MU (Fig. 1) due to difficult terrain conditions in terms of terrain slope and ground obstacles (Đuka et al. 2017).

Data collection of terrain characteristics GIS data of MU and its 16 compartments was taken from the official Management plan (Anonymous 2014). Digital Elevation Model (DEM) was created based on two sets of elevation data obtained by aerialphotogrammetric survey and stereo-restitution processing and digitalization. The DEM was used to extract information regarding terrain gradient (slope) based on Horn's method (Burrough \& McDonnell 1998). Terrain roughness in terms of ground obstacles was described independently of slope by measurements on 319 sample plots regularly distributed in $\mathrm{MU}$, each of $10 \times 10 \mathrm{~m}$ in size and with $100 \mathrm{~m}$ distance (Đuka et al. 2017). On each sample plot, the parameters describing obstacles (height, width and frequency) were recorded according to the methodology of Rowan (1996) for the purpose of defining terrain roughness categories. Data was collected with hand-held GPS with $<10 \mathrm{~m}$ accuracy and a laser rangefinder with $<5 \mathrm{~cm}$ accuracy. Supporting data base was created where roughness classes were determined based on 4 height/depth classes of ground obstacles: (1) H2O (10-30 cm); (2) H4O (31$50 \mathrm{~cm})$; (3) $\mathrm{H} 60$ ( $51-70 \mathrm{~cm})$; (4) $\mathrm{H} 8 \mathrm{O}(>70$ $\mathrm{cm})$; and four frequency classes: (1) iso- lated (4-40 $\left.\mathrm{n} \mathrm{ha} \mathrm{C}^{-1}\right) ;(2)$ infrequent (41-400 $\mathrm{n}$ $\left.h^{-1}\right)$; (3) moderately frequent (401-4000 $\mathrm{n}$ $\left.\mathrm{ha}^{-1}\right)$; and (4) frequent (> $\left.4000 \mathrm{n} \mathrm{ha}^{-1}\right)$. Since there is no available data on ground obstacles in study area, field survey data were then used for raster image creation.

As a consequence, the terrain of the study area was described by two fundamental spatial information: morphology (and derived information) and roughness.

\section{Data collection of primary and secondary forest infrastructure network and analysis}

The existing public and forest roads together with built skid roads were surveyed by a hand-held GPS with accuracy $<10 \mathrm{~m}$. A registry of primary and secondary forest infrastructure network was established according to Pentek et al. (2010) in order to analyse share and lengths of skid roads in each compartment of researched area.

Primary traffic infrastructure consisted of all categories of forest roads as well as local public roads that can be used in forest management (Papa et al. 2015), while secondary forest infrastructure network consisted only of skid roads, i.e., built infrastructural objects with always present earthworks, but without upper road layer (Fig. 1).

Defining extraction distances (use of "Euclidean distance" tool for geometrical extraction distances and "Path distance" tool for real extraction distances) together with relative forest openness, was done by using the ModelBuilder tool incorporated in the programme package $\operatorname{ArcGIS}^{\oplus}$ ver. 10.1. ModelBuilder is a visual programming language for building geo-processing workflows and automating spatial analysis and data management processes. Each model is represented with a diagram that connects sequences of process and geo-processing tools, using the output of one process as the input to another process (ESRI 2017).

All models used in this specific site can be reused and simply modified for use in different conditions regarding terrain, stand and traffic infrastructure network. Input data for each of forest openness parameters is shown in Fig. 2 and generally consists of: (1) polygon data of MU area and its compartments; (2) polyline data of primary traffic infrastructure; (3) polyline data of secondary forest infrastructure network; and (4) DEM, i.e., Digital Terrain Model (DTM) of the researched area.

Geometrical values of timber extraction distances are based on Euclidean distances (the shortest distance to a determined source) and primary traffic infrastructure network (point to point distances), which correlates to already mentioned Segebaden (1964) foundations of determining timber extraction distance. Model for geometrical extraction distances is solely based on two data inputs: (1) polygon shape file of $\mathrm{MU}$ and its compartments; and (2) polyline shape file of primary traffic 
Fig. 1 - Terrain trafficability and primary forest road network in study area (photo 1: terrain conditions, author: A. Đuka; photo 2: timber extraction, author: $\mathrm{T}$. Poršinsky; photo 3: building of a skid road, author: T. Poršinsky).

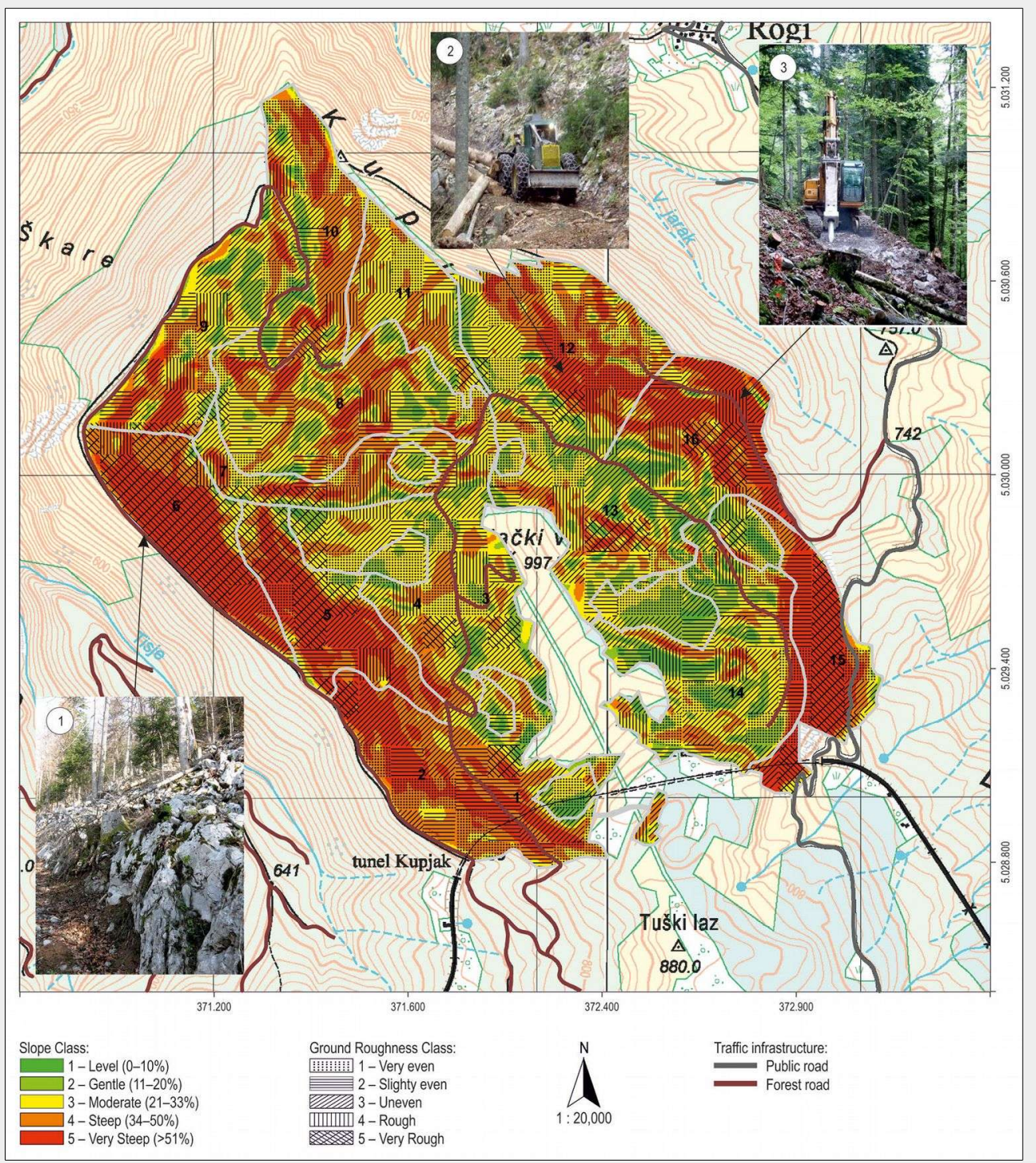

Fig. 2 - Flowchart diagrams of the modeled computational steps for the estimation of extraction distance and forest openness parameters.

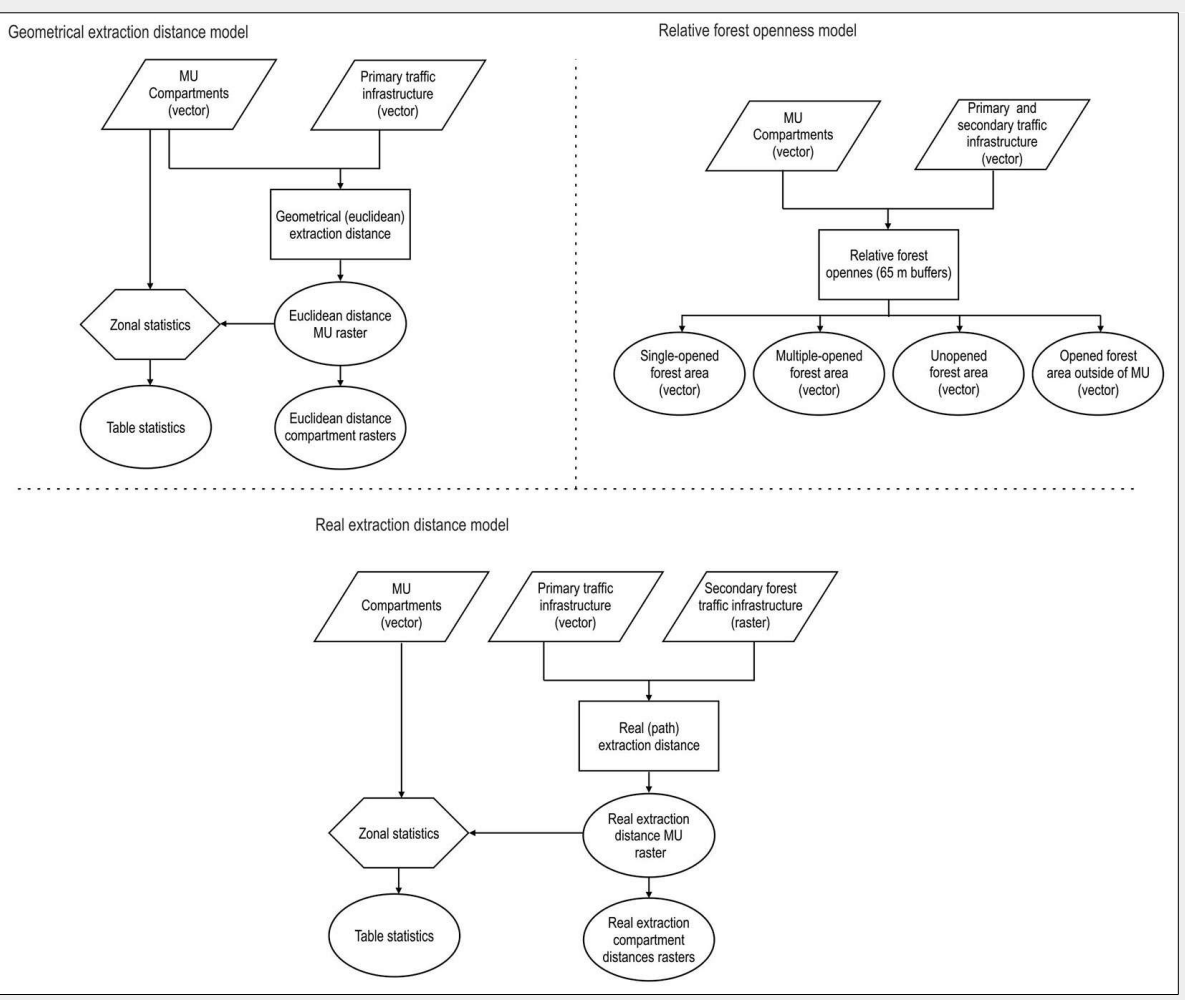


Tab. 1 - Terrain slope and ground roughness classes in the study area.

\begin{tabular}{|c|c|c|c|c|c|}
\hline \multirow{2}{*}{$\begin{array}{l}\text { Terrain } \\
\text { slope classes }\end{array}$} & \multicolumn{2}{|c|}{ Area } & \multirow{2}{*}{$\begin{array}{l}\text { Ground } \\
\text { roughness } \\
\text { classes }\end{array}$} & \multicolumn{2}{|c|}{ Area } \\
\hline & ha & $\%$ & & ha & $\%$ \\
\hline Level & 10.68 & 3.9 & Very even & 45.87 & 16.7 \\
\hline Gentle & 37.78 & 13.7 & Slightly even & 45.94 & 16.7 \\
\hline Moderate & 87.82 & 32.0 & Uneven & 111.88 & 40.7 \\
\hline Steep & 81.34 & 29.6 & Rough & 27.12 & 9.9 \\
\hline Very steep & 57.25 & 20.8 & Very rough & 44.06 & 16 \\
\hline
\end{tabular}

infrastructure network. By using iteration and extraction functions, distinction at the compartment level is possible and statistical data for each compartment can be obtained (pixel count, pixel area, minimum value, maximum value, values range, mean value, standard deviation and sum value).

Relative forest openness calculation was based on both primary and secondary forest infrastructure network and buffer width equal to length of skidder's winch rope $(70 \mathrm{~m})$, reduced for value of mean terrain gradient for the entire management unit. Even though $65 \mathrm{~m}$ winch rope length is the maximal length, it should be noted that terrain conditions regarding steep slope and ground obstacles, as well as the position of rejuvenation areas, will additionally shorten the winch rope length on certain surfaces and compartments, also because of the fact that main operator's stressor when working on a steep slope is moving up and down the slope (Spinelli et al. 2015, Ottaviani Aalmo et al. 2016). The model calculates values for: (1) singleopened forest area (no overlap in buffer area); (2) multiple-opened forest area (overlap in buffer area); (3) unopened forest area (areas beyond $65 \mathrm{~m}$ buffer width); and (4) opened areas outside of the management unit. Multiple opened forest areas can be categorized as poorly planned road network where the same forest area is multiply opened, even though singleopenness should be an imperative. Nevertheless, multiple-opened forest areas are common in every road junction of both primary and secondary forest infrastructure network. Opened areas outside of management unit can be the result of an inadequate setting of the forest traffic infrastructure layout, but with the main focus on ownership or management structure of adjacent forest areas. If a boundary road is used between different forest owners and all benefit from it, maintenance agreement should be in order, otherwise boundary roads should be avoided.

Defining real extraction distances was based on the Path distance tool in ArcGIS, which gives each cell of skid road network least accumulative cost relationship to a source or a set of sources (i.e., forest road network), accounting for surface distance and vertical (slope) cost factors. In this way, actual distances that vehicle (here cable skidder) travels in each compartment while transporting timber to the nearest forest road are based on skid road length, terrain slope and irregularity of both secondary and primary forest infrastructure network, as well as irregularity of compartment's shape and size. The Path distance tool can also consider horizontal constraints (in this case ground obstacles) and therefore it can be used in road planning where both horizontal and vertical terrain factors are used for computing the least accumulative path distance for each future truck or skid road raster cell to the nearest forest road.

While Euclidean distance is the straight line distance between locations, the Path distance tools explore the movement of a traveller over a landscape. The Path Distance tool is the primary tool for cost distance analysis, accounting for both horizontal and vertical cost factors as well as true surface distance. It creates an output raster in which each cell is assigned the accumulative cost from the cheapest source cell. The algorithm utilizes the node/link cell representation, where the center of a cell is considered a node, and each node is connected by links to the nodes adjacent to it. Every link has an impedance associated with it. The impedance is derived from the costs associated with the cells at each end of the link (from the cost surface) and from the direction of movement (ESRI 2017).

This model assumes that cut timber is in reach of skidder winch rope i.e. timber is already collected and vehicle does not descend/ascend from forest infrastructure network to forest stand. Path distance tool also requires precision regarding infrastructure network and $\mathrm{MU} /$ compartment positioning. Boundary roads must strictly be in contact of boundary compartments and there should be no gaps between polygons, otherwise tool will not give correct values.

\section{Used software}

For the creation of DEM, SAGA GIS, Global Mapper and ESRI $\operatorname{ArcGIS}^{\oplus}$ ver. 10.1 were used, while most spatial analysis and creation of model builders was conducted with $\operatorname{ArCGIS}^{\circledast}$ ver. 10.1 and QGIS ver. 2.14.3. Transferring data from GPS to computer was provided using the MapSource ${ }^{\circledR}$ software (Garmin, Switzerland). All statistical analysis was done by the computer package STATISTICA ${ }^{\oplus}$ ver. 7 (StatSoft inc., Tulsa, OK, USA). Figures and maps were modified using the CorelDRAW ${ }^{\circledast} \mathrm{X}_{7}$ package (Corel Corp., Ottawa, Canada).

\section{Results}

\section{Site characteristics}

Based on DEM with $4 \times 4 \mathrm{~m}$ resolution, all five slope classes are evident in the Kupjački vrh MU; terrain gradient above $34 \%$ is the most common and takes $50.4 \%$ of the area (Fig. 1 and Tab. 1). Depending on presence and frequency of ground obstacles, five ground roughness classes were defined from 1 - slightly even terrain to 5 very rough terrain (Tab. 1 and Fig. 1).

Total length of the surveyed forest (truck) roads in this management unit is $8,895 \mathrm{~m}$, while there is one segment of public road (coloured grey in maps) of 967 $m$ in length.

Maximal timber extraction distance in the whole $M U$ and its 28,347 regularly placed network points (generated during raster creation) in the productive forest area is $451 \mathrm{~m}$, while its mean is $126 \mathrm{~m}$ with $99 \mathrm{~m}$ of standard deviation. Highest geometrical extraction distances are in compartments $1,2,7,11,12$, and 14 , with a distance range from 400 to $500 \mathrm{~m}$, while the lowest values with distance below $200 \mathrm{~m}$ are in compartments 2, 15 and 16 (Fig. 3). Still, this is only a two dimensional perspective without accounting the actual terrain morphology.

Relative openness model provided four different area classes in study area depending on buffer placement (inside/outside researched management unit) and overlap occurrence: (1) single opened forest areas 113.03 ha; (2) multiple opened forest areas -126.61 ha; (3) unopened forest areas 39.23 ha; and (4) opened area outside of this MU - 61.64 ha. Fig. 4 summarizes single and multiple opened areas (i.e., areas in reach of skidder's winch rope), together with unopened areas of management unit (i.e., areas out of winch rope reach).

Maximal real extraction distance in the whole management unit is $833 \mathrm{~m}$, with its mean value of $296 \mathrm{~m}$ and $189 \mathrm{~m}$ of standard deviation. By using an elevation raster with $4 \times 4 \mathrm{~m}$ grid resolution, skid road network, polyline primary traffic infrastructure network and $\mathrm{MU} /$ compartments polygons shape files, real extraction distances were obtained, together with descriptive statistics at the compartment level (pixel count, pixel area, minimum and maximum values, value range, mean value, standard deviation and sum value).

Skid road lengths for each compartment and private areas are given in Tab. 2. Overall, 82 skid roads were measured and analysed. Total length of skid roads in this $\mathrm{MU}$ is $22.70 \mathrm{~km}$, which means that skid road density is $82.6 \mathrm{~m} \mathrm{ha}^{-1}$.

Our analysis showed that values of real extraction distances are greater than geometrical extraction distances throughout the entire MU (Fig. 5a), since geometrical approach is based on the shortest linear distance from stand to forest road while 
Fig. 3 - Assessment of the geometrical extraction distances in the study area.

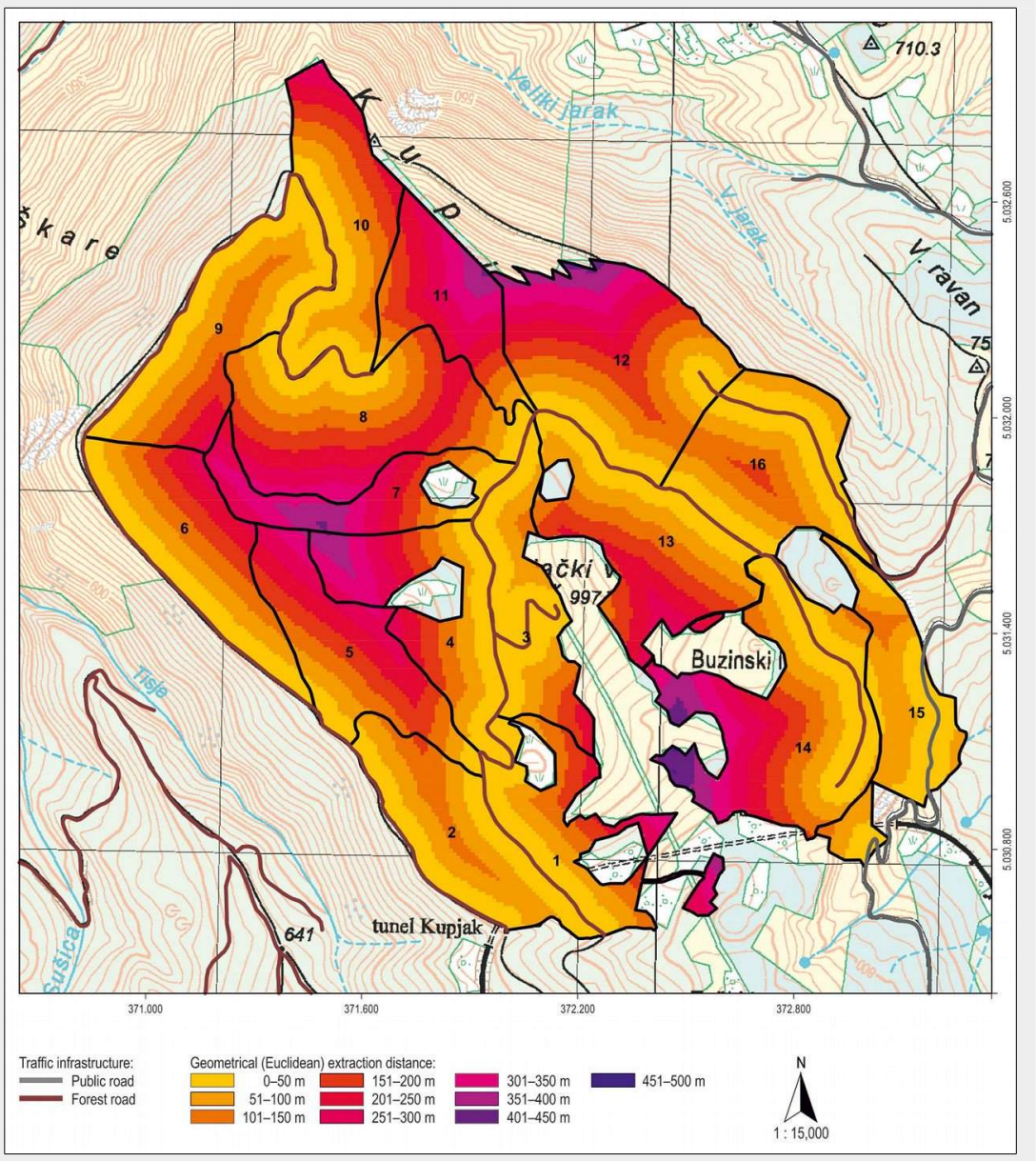

Fig. 4 - Analysis of real extraction distances and relative forest openness in the study area.

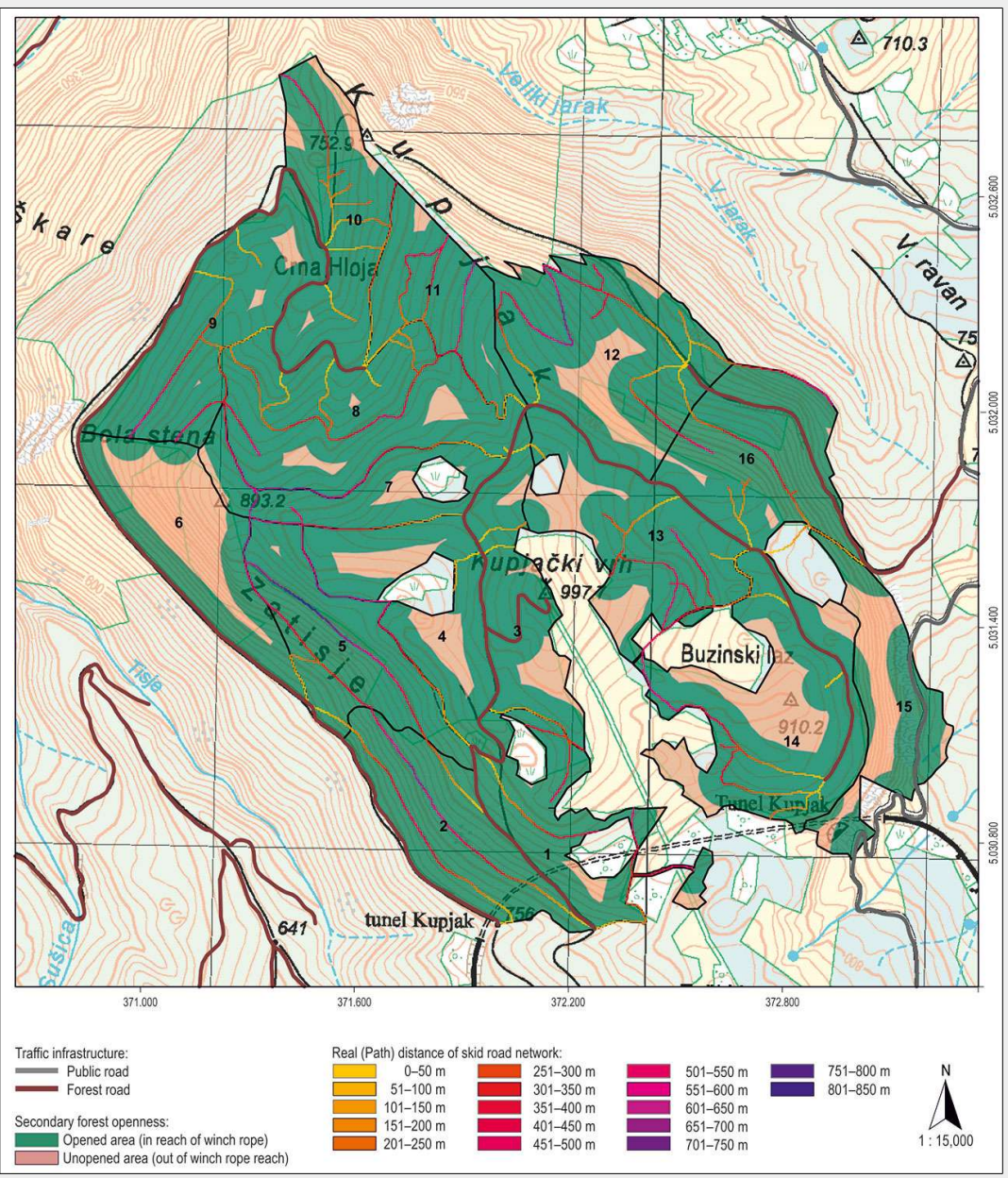


Tab. 2 - Skid roads in the investigated area. (*): boundary skid roads between compartments and/or private enclaves.

\begin{tabular}{|c|c|c|c|c|c|c|c|c|c|}
\hline $\begin{array}{c}\text { Compart- } \\
\text { ment }\end{array}$ & $\begin{array}{l}\text { Length } \\
\text { (m) }\end{array}$ & $\begin{array}{c}\text { Compart- } \\
\text { ment }\end{array}$ & $\begin{array}{l}\text { Length } \\
\text { (m) }\end{array}$ & $\begin{array}{c}\text { Compart- } \\
\text { ment }\end{array}$ & $\begin{array}{l}\text { Length } \\
\text { (m) }\end{array}$ & $\begin{array}{c}\text { Compart- } \\
\text { ment }\end{array}$ & $\begin{array}{l}\text { Length } \\
\text { (m) }\end{array}$ & $\begin{array}{c}\text { Compart- } \\
\text { ment }\end{array}$ & $\begin{array}{l}\text { Length } \\
\text { (m) }\end{array}$ \\
\hline \multirow[t]{5}{*}{1} & 453 & 5 & 725 & $8-11^{*}$ & 769 & 12 & 1371 & 14 & 133 \\
\hline & 132 & & 200 & 9 & 182 & & 81 & & 71 \\
\hline & 192 & & 303 & & 644 & & 86 & & 219 \\
\hline & 182 & $5-6^{*}$ & 406 & & 72 & & 159 & & 374 \\
\hline & 517 & $5-7^{*}$ & 152 & & 149 & & 367 & & 690 \\
\hline \multirow[t]{2}{*}{$1-3^{*}$} & 256 & 7 & 62 & 10 & 153 & & 149 & & 53 \\
\hline & 52 & & 95 & & 164 & & 136 & 15 & 195 \\
\hline \multirow[t]{4}{*}{2} & 857 & $7-8^{*}$ & 1061 & & 187 & 13 & 69 & 16 & 192 \\
\hline & 893 & 8 & 21 & & 112 & & 122 & 16 & 131 \\
\hline & 267 & & 184 & & 77 & & 327 & 16 & 21 \\
\hline & 40 & & 910 & & 30 & & 87 & 16 & 313 \\
\hline \multirow[t]{3}{*}{3} & 66 & & 178 & & 52 & & 347 & 16 & 490 \\
\hline & 97 & & 245 & & 541 & & 258 & 16 & 116 \\
\hline & 162 & & 67 & $10-11^{*}$ & 536 & & 55 & Private & 173 \\
\hline 4 & 163 & & 146 & 11 & 322 & $13-14^{*}$ & 233 & & \\
\hline $4-5^{*}$ & 912 & & 69 & & 257 & 13 - private* & 307 & & \\
\hline $4-7^{*}$ & 461 & $8-9^{*}$ & 325 & & 249 & 14 & 25 & & \\
\hline
\end{tabular}

Tab. 3 - Pearson's correlation coefficients of secondary forest openness indicators in the study area. $(*)$ : $p<0.05$.

\begin{tabular}{lccccc}
\hline Parameter & $\begin{array}{c}\text { Mean geometrical } \\
\text { extraction distance }\end{array}$ & $\begin{array}{c}\text { Mean real } \\
\text { extraction distance }\end{array}$ & $\begin{array}{c}\text { Skid road } \\
\text { density }\end{array}$ & $\begin{array}{c}\text { Opened } \\
\text { area }\end{array}$ & $\begin{array}{c}\text { Skidding } \\
\text { factor }\end{array}$ \\
\hline Mean geometrical extraction distance & 1.000 & $0.569^{*}$ & $0.791^{*}$ & 0.295 & $-0.595^{*}$ \\
Mean real extraction distance & $0.569^{*}$ & 1.000 & $0.557^{*}$ & 0.157 & 0.235 \\
Skid road density & $0.791^{*}$ & $0.557^{*}$ & 1.000 & $0.710^{*}$ & -0.280 \\
Opened area & 0.295 & 0.157 & $0.710^{*}$ & 1.000 & -0.030 \\
Skidding factor & $-0.595^{*}$ & 0.235 & -0.280 & -0.030 & 1.000 \\
\hline
\end{tabular}

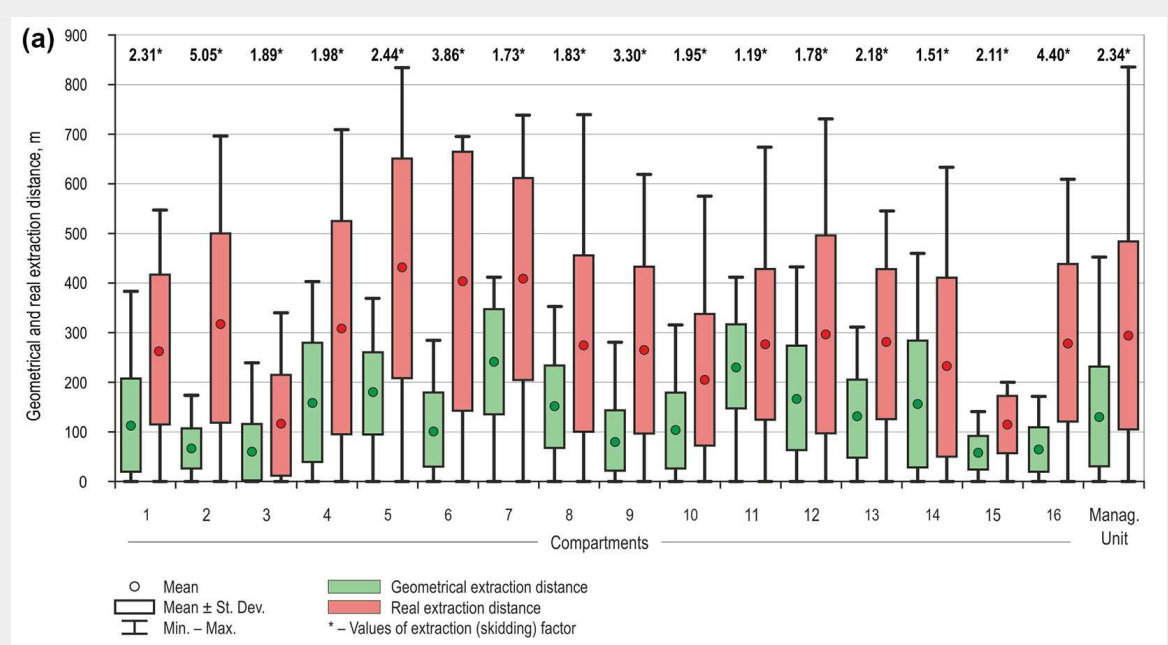

Fig. 5 - (a) Comparison of geometrical and real extraction distances in the study area; (b) Analysis of relative forest openness in the study area.

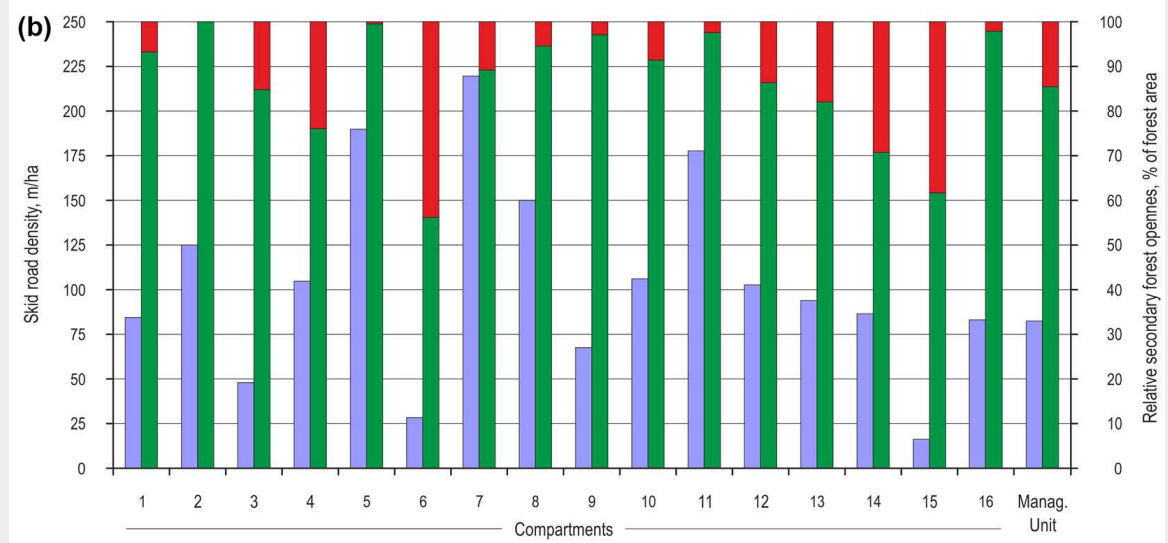


"reality" could be very different. This resulted in variation of extraction (skidding) correction factors at the compartment level from a minumum of 1.19 (compartment 11) to a maximum of 5.05 (compartment 2) in the same management unit (Fig. 5a).

Analysis of skid road density vs. opened forest area (in reach of winch rope) is given in Fig. 5b. Most compartments of the researched management unit have relative openness above $80 \%$.

Descriptive statistics of different extraction distances, relative openness, skid road density and skidding factor is given in Tab. 3. The highest correlation is between mean geometrical extraction distance and skid road density $(r=0.791, p<0.05)$. Since the geometrical approach is based solely on primary forest infrastructure network without considering skid roads, one can conclude that this strong correlation is coincidental. On the other hand, strong correlation between skid road density and opened forest area $(r=0.710, p<0.05)$ is expected, since all parameters are based on the secondary forest infrastructure network. Also, the aforementioned discrepancies between real and geometrical extraction distance have been statistically confirmed with a low correlation $(r=0.569)$.

\section{Discussion}

According to Pentek et al. (2014), primary road density in Croatia, depending on terrain category, ranges from $9.05 \mathrm{~m} \mathrm{ha}^{-1}$ for lowland areas, $11.26 \mathrm{~m} \mathrm{ha}^{-1}$ for hilly areas and $15.43 \mathrm{~m} \mathrm{ha}^{-1}$ for pre-mountainous area. Primary road density for the analyzed MU is $35.87 \mathrm{~m} \mathrm{ha}^{-1}$, which is much higher than mean national values and higher than the $26 \mathrm{~m} \mathrm{ha}^{-1}$ of the karst area of northern-eastern Italy (Pellegrini et al. 2013) or than the $18.5 \mathrm{~m} \mathrm{ha}^{-1}$ of the European mountain region (Enache et al. 2016) or even than the $33.7 \mathrm{~m} \mathrm{ha}^{-1}$ road density of the Austrian federal forests (Osterreichische Waldinventur 1992). However, much higher values (70.90 $\mathrm{m} \mathrm{ha}^{-1}$ ) have been reported for some Austrian areas (district Hermagor in Carinthia Fichtinger 2014).

In this study, the irregularity of management unit and its compartments shape, as well as the irregularity of primary traffic infrastructure network itself, which are the consequence of varying terrain conditions, resulted in the discrepancy between geometrical and real extraction distances (Fig. 5a). Such discrepancy is due to terrain characteristics (terrain slope and presence of ground obstacles). Ground obstacles and terrain roughness, even not directly included in presented models for calculating real extraction distances, are common in karst terrain and actually had affected the layout of skid road network during its planning and design and thus indirectly have affected skid road lengths.

According to Rebula (1983), secondary road density in young stands should be 250-300 m ha-1 while in older stands with lower density it should be $100-180 \mathrm{~m} \mathrm{ha}^{-1}$. Zdjelar (1990) concludes that for this area of Croatia (pre-mountainous terrain of Gorski kotar) and selective forests, optimal secondary road openness should be $150 \mathrm{~m}$ ha ${ }^{-1}$, though it should be noticed that data on national level regarding secondary road density still does not exist.

Regarding the relative openness (Fig. 5b), 12 compartments have excellent (>80\%) relative openness, according to Dietz et al. (1984), while only two compartments (No. 6 and 15) are insufficiently relatively opened. These last two values did not affect the overall $\mathrm{MU}$ relative openness $(85.92 \%)$. The reason of such low values for compartments 6 and 15 can be found in the fact that these are actually protective forests, where more than $60 \%$ of the area has terrain slope higher than $51 \%$ and very rough (class 5 ) ground conditions prevail.

Mean real extraction distance in the analyzed MU is $296 \mathrm{~m}$ and an excellent relative forest openness is present in 12 of totally 16 compartments with "only" $82.6 \mathrm{~m} \mathrm{ha}^{-1}$ skid road density. This result highlights a good forest traffic infrastructure layout, especially considering that this is the area of high karst, sloped terrain, clear presence of ground obstacles and existence of private enclaves (Fig. 1). Real extraction distances at operational level of planning timber extraction should be considered in the context of secondary road density and in the context of (un)opened compartments' areas (Fig. 5a, Fig. 5b).

\section{Conclusions}

The proposed method for determining extraction distances at compartment level is based on primary and secondary forest infrastructure network registry, digital terrain model and limited vehicle movement solely on forest infrastructure network without leaving it and descending/ascending into the forest stand. The observed differences in extraction distance obtained using the proposed and the geometrical methods make unjustified the use of correction factors, which is frequently reported in the literature, as variations ranging from 1.19 to 5.05 within the same management unit were present. Therefore, planning harvesting operations (timber extraction) at the operational level should not include the use of correction factors previously obtained for entire terrain categories, sub-categories or even management units.

Despite our study area was relatively small ( $278.80 \mathrm{ha})$, consisting of only 16 compartments, the proposed model can be freely applied with minor modifications in different harvesting systems, forest stands and management regimes, in order to obtain geometrical extraction distance, relative forest openness and real extraction distance. Moreover, model quality can be further improved with the use of highdefinition Digital Elevation Model based on LiDAR data. Indeed, a high-definition ter- rain description based on LiDAR data could allow a better accuracy of the results, and a more precise measurement of ground obstacles, which is a time-consuming activity in the field.

In this study, the cumulative path distance for each cell of the skid road raster to the nearest forest road was modeled, taking into consideration both horizontal and vertical constraints. The use of digital terrain models and advanced spatial techniques has proved to effectively support decision planning of secondary and primary forest infrastructure network for timber extraction in productive selective cut forests.

\section{References}

Ackerman P, Pulkki R, Gleasure E (2014). Modelling of wander ratios, travel speeds and productivity of cable and grapple skidders in softwood sawtimber operations in South Africa. Southern Forests: a Journal of Forest Science 76 (2): 101-110. - doi: 10.2989/20702620.2014.91 7355

Ackerman P, Pulkki R, Odhiambo B (2016). Comparison of cable skidding productivity and cost: pre-choking mainline versus tagline systems. Croatian Journal of Forest Engineering 37 (2): 261-268. [online] URL: http://www.crojfe.com/ r/i/crojfe_37-2_2016/Ackerman.pdf

Allman $M$, Ferenčík $M$, Jankovský $M$, Stanovský M, Messingerová V (2015). Damage caused by wheeled skidders on Cambisols of central Europe. Croatian Journal of Forest Engineering 36 (2): 205-215. [online] URL: http://www.crojfe. com/r/i/crojfe_36-2_15/allman.pdf

Amishev D, Evanson T, Raymond K (2009). Felling and bunching on steep terrain - a review of the literature. Harvesting Technical Note 1 (7), Future Forests Research Limited, Rotorua, New Zealand, pp. 10. [online] URL: http:// www.ffr.co.nz/felling-and-bunching-steepterrain--review-literature

Anonymous (2014). Program gospodarenja šumama posebne namjene - nastavno pokusni šumski objekt Zalesina GJ Kupjački vrh 1.1: 201531.12.2024 [Management program for special purpose forests - forest training and research center Zalesina, Management unit Kupjački vrh 1.1: 2015-31.12.2024]. Faculty of Forestry University of Zagreb, Zagreb, Croatia, pp. 1-75. [in Croatian]

Backmund F (1966). Kennzahlen für den Grad der Erschließung von Forstbetrieben durch autofahrbare Wege [Key figures for defining the accessibility of forestry enterprises throughout road network]. Forstwissenschaftliches Centralblatt 85(11-12): 342-354. [in German] - doi: 10.1007/BF02202207

Bont LG, Heinimann HR, Church RL (2012). Concurrent optimization of harvesting and road network layouts under steep terrain. Annals of Operations Research 232 (1): 41-64. - doi: 10.100 7/s10479-012-1273-4

Burrough PA, McDonnell RA (1998). Principles of GIS. Oxford University Press, London, UK, pp. 333.

Cambi M, Certini G, Neri F, Marchi E (2015). The impact of heavy traffic on forest soils: a review. Forest Ecology and Management 338: 124-138. - 
doi: 10.1016/j.foreco.2014.11.022

Cambi M, Grigolato S, Neri F, Picchio R, Marchi E (2016). Effects of forwarder operation on soil physical characteristics: a case study in the Italian Alps. Croatian Journal of Forest Engineering 37 (2): 233-239. [online] URL: http://hrcak.srce. $\mathrm{hr} / 173823$ ?lang=en

Cavalli R, Grigolato S (2010). Influence of characteristics and extension of a forest road network on the supply cost of forest woodchips. Journal of Forest Research 15 (3): 202-209. - doi: 10.1007/s10310-009-0170-4

Contreras M, Chung W (2007). A computer approach to finding an optimal log landing location and analysing influencing factors for ground-based timber harvesting. Canadian journal of forest research 37 (2): 276-292. - doi: 10.1139/x06-219

Contreras M, Chung W (2011). A modeling approach to estimating skidding costs of individual trees for thinning operations. Western Journal of Applied Forestry 26 (3): 133-146. [online] URL: http://www.ingentaconnect.com/conten t/saf/wjaf/2011/00000026/00000003/art00006

Dietz P, Knigge W, Löffler H (1984). Walderschließung [Forest openness]. Verlag Paul Parey, Hamburg, Germany, pp. 426. [in German]

Đuka A, Vusić D, Poršinsky T (2017). Terrain roughness evaluation for timber extraction by cable skidder. Gozdarski Vestnik 75 (1): 21-35.

Enache $A$, Kühmaier $M$, Visser $R$, Stampfer $K$ (2016). Forestry operations in the European mountains: a study of current practices and efficiency gaps. Scandinavian Journal of Forest Research 31 (4): 412-427. - doi: 10.1080/028275 81.2015.1130849

ESRI (2017). ArcMap. Web site. [online] URL: http://desktop.arcgis.com/en/

Fichtinger C (2014). Analyse der forstlichen Erschließungssituation und Tragfähigkeit von Forststraßen im Bezirk Hermagor (Kärnten) [Analysis of the forestry development and sustainability of forest roads in the district of Hermagor (Carinthia)]. MSc thesis, Department of Forest and Soil Sciences, University of Natural Resources and Life Sciences, Vienna, Austria, pp. 54. [in German]

Folegatti B (2010). The application of precision forestry technologies in logging operations. MSc thesis, Department of Forestry and Wildlife Sciences, Auburn University, Auburn, AL, USA, pp. 138. [online] URL: http://search.pro quest.com/openview/77d5b57d2b89afodc4169 bee 4 d398ac9/1

Greulich FE (1997). An algorithm for optimal centralized landing location: rectilinear yarding operations on flat uniform terrain. Canadian Journal of Forest Research 27 (8): 1192-1197. doi: 10.1139/x97-029

Grigolato S, Pellegrini M, Cavalli R (2013). Temporal analysis of the traffic loads on forest road networks. iForest 6 (5): 255-226. - doi: 10.3832/ iforo773-006

Grigolato S, Mologni O, Cavalli R (2017). GIS applications in forest operations and road network planning: An overview over the last two decades. Croatian Journal of Forest Engineering 38 (2): 175-186. [online] URL: http://www. crojfe.com/r/i/crojfe_38-2_2017/grigolato.pdf

Halleux ORM, Greene WD (2001). Setting analyst: a practical harvest planning technique. In:
Proceedings of the " $24^{\text {th }}$ Annual Council on Forest Engineering Meeting Appalachian hardwoods managing change" (Wang J, Wolford $M$, McNeel J eds). Snowshoe (WV, USA), 15-19 July 2001. Council on Forest Engineering, Corvallis, OR, USA, pp. 127-132.

Hayati E, Majnounian B, Abdi E (2012). Qualitative evaluation and optimization of forest road network to minimize total costs and environmental impacts. iForest 5 (3): 121-125. - doi: 10.3832/iforo610-009

Heinimann HR (1999). Ground-based harvesting technologies for steep slopes. In: Proceedings of the "International Mountain Logging and $10^{\text {th }}$ Pacific Northwest Skyline Symposium" (Sessions J, Chung W eds). Oregon State University, Corvallis (OR, USA), 28 Mar - 1 Apr. Department of Forest Engineering, Oregon State and International Union of Forest Research Organization, Corvallis, OR, USA, pp. 1-19.

Herak M, Stringfield VT (1971). Karst, important karst regions of the northern hemisphere. Elsevier Science Ltd, The Netherlands, pp. 556.

Jourgholami M, Abdi E, Chung W (2013). Decision making in forest road planning considering both skidding and road costs: a case study in the Hyrcanian forest in Iran. iForest 6 (2): 5964. - doi: 10.3832/iforo640-006

Krč J, Košir B (2008). Predicting wood skidding direction on steep terrain by DEM and forest road network extension. Croatian Journal of Forest Engineering 29 (2): 177-188.

Kulak D, Stanczykiewicz A, Szewczyk G (2017). Productivity and time consumption of timber extraction with a grapple skidder in selected pine stands. Croatian Journal of Forest Engineering 38 (1): 55-63. [online] URL: http://hrcak. srce.hr/index.php?show=clanak\&id_clanak_jezi $\mathrm{k}=257412$ \&lang=en

Leucci G, De Giorgi L (2005). Integrated geophysical surveys to assess the structural conditions of a karstic cave of archaeological importance. Natural Hazards and Earth System Science 5 (1): 17-22. - doi: 10.5194/nhess-5-17-2005

Lopes SE, Fernandes HC, Vieira LB, Machado CC, Rinaldi PCN (2006). Evaluation of compaction of a forest soil subjected to skidder traffic. Revista Arvore 30 (3): 369-376. - doi: 10.1590/ S0100-67622006000300007

Marchi E, Picchio R, Spinelli R, Verani S, Venanzi $R$, Certini G (2014). Environmental impact assessment of different logging methods in pine forests thinning. Ecological Engineering 70: 429-436. - doi: 10.1016/j.ecoleng.2014.06. 019

Matthews DM (1942). Cost control in the logging industry. McGraw-Hill Book Company Inc., New York City, NY, USA, pp. 1-374. [online] URL: http://www.cabdirect.org/cabdirect/abstract/19 420617206

Osterreichische Waldinventur (1992). Instruktion für die Feldarbeit der Österreichischen Waldinventur 1992/96 [Instructions for Austrian Forest Inventory]. Web site. [in German] [online] URL: http://bfw.ac.at/rz/wi.home

Ottaviani Aalmo G, Magagnotti N., Spinelli R (2016). Forest workers and steep terrain winching: The impact of environmental and anthropometric parameters on performance. Croatian Journal of Forest Engineering 37 (1): 97-105. [online] URL: http://www.crojfe.com/rli/crojfe 37-1_2016/Ottaviani.pdf

Papa I, Pentek T, Nevečerel H, Lepoglavec K, Đuka A, Šafran B, Risović S (2015). Raščlamba tehničkih značajki i sustava odvodnje postojećih šumskih cesta radi utvrdivanja potrebe njihove rekonstrukcije - studija slučaja za GJ Belevine NPSO Zalesina [The analysis of the technical features and drainage system for existing forest roads in order to establish the needs of their reconstruction - a case study of MU Belevine FTRC Zalesina]. Šumarski list 139 (11-12): 497-517. [in Croatian]

Pellegrini M, Grigolato S, Cavalli R (2013). Spatial multi-criteria decision process to define maintenance priorities of forest road network: an application in the Italian alpine region. Croatian Journal of Forest Engineering 34(1): 31-42. [online] URL: http://hrcak.srce.hr/index.php? show=clanak\&id_clanak_jezik=172576\&lang=en Pentek T, Nevečerel H, Dasović K, Poršinsky T, Šušnjar M, Potočnik I (2010). Analiza sekundarne otvorenosti šuma gorskog područja kao podloga za odabir duljine uža vitla [Analysis of secondary relative openness in hilly areas as a basis for selection of winch rope length]. Šumarski list 134 (5-6): 241-248. [in Croatian]

Pentek T, Nevečerel H, Ecimović T, Lepoglavec K, Papa I, Tomašić Z (2014). Strategijsko planiranje šumskih prometnica u Republici Hrvatskojraščlamba postojećega stanja kao podloga za buduće aktivnosti [Strategic planning of forest road network in Croatia-analysis of present situation as basis for future activities]. Nova mehanizacija Šumarstva 35 (1): 63-78. [in Croatian] Pentek T, Pičman D, Nevečerel H (2004). Srednja udaljenost privlačenja drva [Mean wood skidding distance]. Šumarski list 128(9-10): 545-558. [in Croatian]

Rebula E (1983). Optimalna gustoća traktorskih vlaka [Optimal skid road density]. Mehanizacija šumarstva 8 (3-4): 317-321. [in Croatian]

Rowan AA (1996). Terrain classification. Forestry Record 114, Forestry Commission, Her Majesty's Stationery Office (HMSO), Edinburgh, UK, pp. 124.

Segebaden G (1964). Studies of cross-country transport distances and road net extension. Studia Forestalia Suecica 18: 1-70. [online] URL: http://pub.epsilon.slu.se/12770/1/SFS018.pdf

Sessions J (2007). Harvesting operations in the tropics. Springer-Verlag, Berlin, Heidelberg, Germany, pp. 170. - doi: 10.1007/978-3-540-463 91-7

Silversides CR, Sundberg U (1988). Operational efficiency in forestry - volume 1. Analysis. Kluwer Academic Publishers - Forest Sciences, Dordrecht/Boston/Lancaster, Netherlands, pp. 219. - doi: 10.1007/978-94-017-0504-2

Solgi, A, Naghdi, R, Tsioras, PA, Nikooy, M (2015). Soil compaction and porosity changes caused during the operation of Timberjack $450 \mathrm{C}$ skidder in northern Iran. Croatian Journal of Forest Engineering 36 (2): 217-225. [online] URL: http:// hrcak.srce.hr/index.php?show=clanak\&id_clan ak_jezik=223302

Spinelli R, Aalmo GO, Magagnotti N (2015). The effect of a slack-pulling device in reducing operator physiological workload during log winching operations. Ergonomics 58 (5): 781-790. doi: $10.1080 / 00140139.2014 .983184$ 
Stückelberger J, Heinimann HR, Chung W (2007). Improved road network design models with the consideration of various link patterns and road design elements. Canadian Journal of Forest Research 37 (11): 2281-2298. - doi: 10.1139/Xo 7-036

Valeria O, Cea I, Bergeron Y (2011). A review of skidding distances method under variable retention harvesting considerations. In: Proceedings of the " $34^{\text {th }}$ Council on Forest Engineering”. Université Laval, Quebec City (Quebec, Canada) 12-15 June 2011. Université du Québec en Abitibi-Témiscamingue, RouynNoranda, Canada, pp. 1-12. [online] URL: http:// www.cirrelt.ca/cofe2011/proceedings/35- valeria.pdf

Visser R, Berkett H (2015). Effect of terrain steepness on machine slope when harvesting. International Journal of Forest Engineering 26 (1): 1-9. - doi: 10.1080/14942119.2015.1033211

Visser R, Stampfer K (2015). Expanding groundbased harvesting onto steep terrain - a review. Croatian Journal of Forest Engineering 36 (2): 321-331. [online] URL: http://hrcak.srce.hr/ind ex.php?show=clanak\&id_clanak_jezik $=223383 \&$ lang=en

Waltham AC, Fookes PG (2003). Engineering classification of karst ground conditions. Quarterly Journal of Engineering Geology and Hydrogeology 36 (2): 101-118. - doi: 10.1144/1470-
9236/07-224

Zdjelar M (1990). Utjecaj metoda gradnje traktorskih vlaka na proizvodnost i ekonomičnost rada, oštećivanje stabala i naprezanje radnika [The impact of skid road construction methods on work productivity and efficiency, tree damage and work load]. Mehanizacija šumarstva 15 (1-2): 3-26. [in Croatian]

Zhang ZH, Hu G, Zhu JD, Luo DH, Ni J (2010). Spatial patterns and interspecific associations of dominant tree species in two old-growth karst forests, SW China. Ecological research 25 (6): 1151-116o. - doi: 10.1007/s11284-010-0740-0 